\title{
Keeping the brain in mind: why neuroscience matters to 21 st-century psychiatrists
}

\author{
Derek K. Tracy $\mathbb{~}$ ()
}

\begin{abstract}
SUMMARY
Psychiatry intertwines mind and brain, sometimes in a strained marriage. Psychiatrists feel the criticism of a 'narrow' biological or medical (and medication) focus, and we are very aware of the limitations of all treatments and diagnostic systems. Many understandably move towards a more social approach, seeing individuals in their wider lives. But there are dangers in losing the brain, something unique to our specialty in the world of mental health. This reflective piece calls for us to rediscover the joy of the science of the brain, which augments, not conflicts with, psychosocial approaches.
\end{abstract}

\section{KEYWORDS}

Neuroscience; psychiatry; education and training.

\section{Time present and time past ${ }^{\mathrm{a}}$}

'Have you reckon'd a thousand acres much? have you reckon'd the earth much?

Have you practis'd so long to learn to read? Have you felt so proud to get at the meaning of poems?

Stop this day and night with me and you shall possess the origin of all poems, You shall possess the good of the earth and sun (there are millions of suns left)'

Walt Whitman, 'Song of Myself' (1892)

Three and a half billion years in the making from star dust. Ten million years sculpting hominin prefrontal perfection while never escaping that phylogenetically ancient, powerful, driving limbic system. One hundred billion neurons, one thousand trillion synaptic connections. The most sophisticated device in the known universe. So god-like, so frail. So human, so you, so me. Ecce Homo.

Do you remember the wonder and joy with which you once beheld that? Adolescent late-night conversations on the nature of existence, the essence of consciousness, the seat and meaning of a soul? Alongside your love of literature, of art, of humanities. The dual aspects that drew you first to medicine, and then ultimately to psychiatry: the science of the brain with the poetry of what it meant to be human. Where do we lose it, the brain part?

I have aversive med school memories of obtuse black and white drawings in neuroanatomy textbooks. Lines pointing to brain regions that seemed unconnected to each other and certainly to those on the following page, which had leapt suddenly and unexplained from sagittal to coronal section (and which was which anyway?). I have, I confess, unpleasant recollections of the MRCPsych examination by MCQ on neuroscience, including inexplicable questions on baboon social behaviour (whose hobby-horse was that?). Names seemingly for names' sake, lists seemingly solely for examination. Endured but never loved.

\section{Are both perhaps present in time future}

\author{
'Be in me as the eternal moods \\ of the bleak wind, and not \\ as transient things are - \\ gaiety of flowers. \\ Have me in the strong loneliness \\ of sunless cliffs \\ and of grey waters'
}

Ezra Pound, ‘ $\Delta \omega \dot{\rho} \propto \alpha^{\prime}(1912)$

We all become social psychiatrists in the end. It's the job, and it is human nature. We move from university environments to clinics and communities. We grow from seeing illnesses in people to seeing people in their wider lives. We see what counts most to them, and we see what most affects them: sometimes it is medication, usually it isn't. We feel it, the humanity of it: the mind exceeding the sum of the brain's parts, family and society greater than the individual. We embody Turgenev's ontogeny from youthful scientist to a deeper more worldly wisdom of age (Turgenev 1867).

Yet. Is that narrative complete, or just a helpful anaesthesia? Do we fear that we forget? How well could you examine the cranial nerves now, or point on an atlas to periaqueductal grey matter? Do you recall Mendelian changes in pea plants and eye colour described in childhood school texts, but
CLINICAL REFLECTION
Derek Tracy is a consultant psychiatrist and Clinical Director at Oxleas NHS Foundation Trust, London, and a senior lecturer at the Institute of Psychiatry, Psychology and Neuroscience, King's College London, UK.

Correspondence Dr Derek K. Tracy. Email: derek.tracy@nhs.net

First received 3 Jan 2020

Accepted 13 Feb 2020

Copyright and usage (C) The Author 2020 
question yourself when 'epi' is placed in front of 'genetic'? GWAS turns you cold, and what has pharmacogenomics ever done for you (or anyone you've treated)?

Do we fear that we alienate our patients? Do you call them patients anymore? We agree that we have rightfully shifted from a paternalistic system of care, and perhaps away from a largely medical model (though quite what that means I'm not so sure). We embrace the constructs of empowered codesign and experts by experience, even if the phrases themselves clunk and jar like Orwellian Newspeak. Have we gone from a strategy of brain in one hand and mind in the other to publicly disavowing and decommissioning the former in embarrassment as part of a peace and reconciliation process with a wider community?

\section{And time future contained in time past}

'may my heart always be open to little birds who are the secrets of living whatever they sing is better than to know and if men should not hear them men are old' e e cummings, 'may my heart always be open' (1960)

We know the dichotomy is false. We are not psychologists, social workers or psychiatric nurses, though we take aspects of each of those professions in our thinking and practice. We also have something different, something extra as medical doctors and scientists of the human. Our understanding of the physicalities of our bodies, including our brains, is unique. Neurologists track the wiring, but we know the software code that flows within; they can see the depolarisation, we can also read the love and anger and hope and fear that it Morses.

Biopsychosocial is rightly reversing to sociopsychobio in emphasis, but one never escapes the bio. To see our patients - or clients, or service users without the biological is as foolish as seeing them without the social. One needs the other. To understand the amygdala and hippocampus in someone who has suffered trauma is as important for a psychiatrist as understanding the context and meaning of those experiences for the individual.

Change comes slower than we would like. We are frustrated that the 'Decade of the Brain' has been and gone, and translational aspects of neuroscience have at times felt staler than tabloid headlines proclaiming miracle cures for this and that. But it is coming. 21st-century psychiatry and neuroscience will undo our current, flawed diagnostic systems that are based on descriptive phenotypes. They will advance our understanding of why some individuals develop the problems they do, and they will provide better future treatments, including (inevitably fuzzy) predictive models for interventions. This will integrate with psychological and social interventions. The biological alone could never replace them; but nor could the psychosocial without the biological.

To deny this is to deny science - and that is not who you are. To deny this is to deny that genetic differences in people can be as important as the differences in their experiences (which alters their gene expression - there's the 'epi' bit); to deny this is to deny that the same medication helps one person but not another with the same problem (which you see in practice daily). We can see what we need to do to overcome, to unpick; a rational argument can surely only ask when, not if.

'When I became a man, I put away childish things'. Well don't. Rediscover joy and the part of you that was once excited; trainees and medical students will be a good place to start, lacking our protective, defensive cynicism. Learn together, be at peace with not fully understanding, with feeling confused. This special edition of BJPsych Advances is full of excitement, and wonder, and the scholarship is real and hot. The poetry is there in the science as much as it is in the humanity of our practice. To not feel it is to be disappointed to learn that light from some stars you see in the night sky comes not from candles lit by angels but has travelled for twelve thousand years - from before humans discovered agriculture - to finally fall and evoke an action potential in your retina.

Scepticism is good, frustration is fine, but you have chosen to work with that most complicated device in the known universe. Oh, to be a cardiologist and just worry about how fast or slow or regular (or leaky) a pump is; to be a nephrologist trying to flush out a sieve or a urologist a blocked pipe; to be an orthopod clanking and banging around with a hammer and saw. But no, you chose consciousness, love, fear and poetry. You chose the brain. And good for you; so did I.

\section{Declaration of interest}

None.

\section{References}

Cummings EE (1960) Selected Poems 1923-1958. Faber \& Faber.

Eliot TS (1943) Four Quartets. Harcourt.

Pound E (1912) Ripostes. Swift \& Co.

Turgenev I (1867) Fathers and Sons. Leypoldt and Holt.

Whitman W (1892) Leaves of Grass. David McKay. 